\title{
ANALISIS IMPLEMENTASI PROGRAM PEMBERDAYAAN EKONOMI MASYARAKAT PESISIR (PEMP) DI DUSUN TAMAN DESA TAMAN AYU KECAMATAN GERUNG KABUPATEN LOMBOK BARAT
}

\author{
Junaidin ${ }^{1}, *, \mathrm{Hj}$. Mas'ad $^{2}$ \\ 1 UM Mataram \\ ${ }^{2}$ UM Mataram
}

\begin{abstract}
Abstrak
Penelitian ini bertujuan untuk mendeskripsikan evaluasi serta perkembangan yang terjadi atas pelaksanaan kebijakan pelaksanaan program Pemberdayaan Ekonomi Masyarakat Pesisir (PEMP) di Dusun Taman Desa Taman Ayu Kecamatan Gerung Kabupaten Lombok Barat Tahun 2015. Metode yang digunakan adalah metode penelitian deskriptif dengan pendekatan kualitatif, pengumpulan data menggunakan wawancara, pengamatan yang sudah dituliskan dalam catatan lapangan, dokumen pribadi, dokumen resmi, gambar, foto dan sebagainya. Sedangkan analisis data menggunakan metode model alir (flow model) yang meliputi tahap: (a) reduksi data, (b) penyajian data, dan (c) penarikan kesimpulan serta verifikasi. Berdasarkan hasil penelitian dan pembahasan terhadap fokus permasalahan dalam penelitian ini, maka dapat diambil beberapa kesimpulan sebagai berikut: (a) Pelaksanaan kebijakan PEMP dalam pemberdayaan masyarakat miskin di Kecamatan Gerung terdiri dari empat tahap, antara lain yaitu tahap persiapan; tahap pelaksanaan; tahap pengendalian; dan tahap pelestarian. Pemanfaatan dana bantuan telah sesuai dengan tiga komponen kegiatan yang menjadi sasaran tujuan program PEMP, yaitu ekonomi produktif; pelatihan dan pembangunan sarana dan prasarana dasar lingkungan. Namun masih ada sejumlah anggota KSM yang memanfaatkan bantuan tersebut untuk kegiatan konsumtif. Pembentukan BKM dan KSM dilaksanakan secara demokratis, transparansi, dan jujur, karena kedua lembaga lokal inilah yang berinteraksi dalam pelaksanaan PEMP.
\end{abstract}

\author{
Keywords: \\ Implementasi \\ Pemberdayaan \\ Masyarakat, Partisipasi, \\ Dampak
}

\section{PENDAHULUAN}

Rencana Pembangunan Jangka Panjang Nasional (RPJN) tahun 20102014 menjelaskan bahwa kurun waktu tahun 2004-2008 perekonomian Indonesia cenderung membaik. Hal ini ditunjukkan dengan naiknya pertumbuhan ekonomi dari 5,0 persen pada tahun 2004 kemudian meningkat menjadi 6,3 persen pada tahun 2007 merupakan tingkat pertumbuhan ekonomi yang untuk pertama kalinya di atas 6,0 persen sejak krisis ekonomi tahun 1998. Pertumbuhan ekonomi Indonesia selama tahun 2008 mencapai 6,1 persen. Dari sisi pennintaan, pertumbuhan ekonomi pada tahun 2008, terutama, didorong oleh investasi berupaa Pembentukan Modal Tetap Domestik Bruto (PMTB) dan ekspor barang dan jasa yang masing-maSing tumbuh sebesar 11,7 persen dan 9,5 persen. Dari sisi produksi, pertumbuhan ekonomi pada tahun 2008, terutama, didorongoleh sektor pertanian yang tumbuh 4,8 persen. Sementara itu, investasi di bidang kelautan dan pesisr masih terbatas oleh adanya kebijakan pemerintah daerah (provinsi, kabupaten/kota dan desa) dalam rencana tata ruang wilayah yang masih tumpang tindih dan belum searah.

Berbagai permasalahan dan tantangan yang dihadapi adalah sebagai berikut seperti potensial wisata bahari, pemberdayaan para, nelayan, petani tambak ikan dan garam, petani nunput laut, habitat ekosistim laut dan pesisir, dan pengawasan pemerintah serta bioteknologi kelautan sebagai bentuk inovasi energi kelautan. Upaya pengembangan ekonomi ma-syarakat pesisir, selain bertujuan untuk meningkatkan pertumbuhan ekonomi dalam rangka peningkatan daya saing ekonomi daerah, tetapi juga untuk memeratakan pembangunan ekonomian antar wilayah yang berkeadilan melalui peningkatan daya saing daerah. 
Luasnya pengaruh program PEMP di desa, menandakan bahwa pentingnya masa depan desa ditinjau dari aspek ekonomi pesisir dan kelautan dalam menghadapi ancaman kapital modem. Berawal dari masyarakat nelayan sebagai komunitas wilayah pesisir dan berangkat dari kondisi terpinggirkan dan pembangunan sehingga keludupan nelayan menggantung nasib path hasil laut degan pola sederhana atau traditionale producted seperti alat, bahan dan tata cara operasi produksi sertarendahnya daya jelajah nelayan, menuju kebebasan berfikir, bergerak dan berkreasi berbasis kesholehan sosial dan secara khusus program pemberdayakan masyarakat pesisir berarti menciptakan peluang kreasi dan inovasi bagi masyaraakat serta memaksimalkan pengelolaan sumber daya menuju msayarakat padat karya untuk memenuhi kesejahteraan.

Pemanfaatan elemen modal sosial merupakan prasyarat dalam upaya pemberdayaan komunitas, khususnya komunitas pesisir. Sejalan dengan pendapat diatas, pemerintah memandang perlu adanya upaya dalam bentuk program yang berkelanjutan dan menyentuh langsung kesasarannya. Salah satu program yang bertujuan dan mendukung kearah tersebut adalah Program Pemberdayaan Ekonomi Masyarakat Pesisir (PEMP). Program ini telah berjalan sejak tahun 2001, dimana tujuan dari program ini adalah penguatan ekonomi dengan modal usaha ekonomi produktif yang berasal dari masyarakat.

Berdasarkan pengamatan awal peneliti bahwa di Dusun Taman Desa Taman Ayu Kecamatan Gerung Kabupaten Lombok Barat. Implementasi program PEMP di desa secara ideal tidak berorientasi pada target group dan memperhatikan kelanjutan program, proses pendidikan dan peningkatan sumber daya manusia serta pelembagaan pembangunan.Untuk kepentingan tersebut, perlu dilakukan studi implementasi program dengan model atau pola yang dilakukan pemerintah secara sistematis untuk mengetahui efisiensi dan efektifitas pencapaian sasarau, serta faktor-faktor lain yang dapat mendukung atau penghambat pelaksanaan program karena salah satu kelemahan dalam pelaksanaan program pada umumnya adalah kurangnya perhatian kerja pemerintah setelah program disalurkan ke bawahnya. Antara penelitian ini dengan program PEMP pada akhirnya akan terdapat kesesuaian antara pola pelaksanaan dengan kondisi daerah desa relokasi program yang menyangkut fisik, moneter dan kondisi manuasinya sebagai objek sasaran proogram.

Dalam penelitian ini peneliti mencoba untuk mendeskripsikan kondisi lingkungan masyarakat desa terhadap efisiensi dan efektifitas pola pelaksanaan PEMP kedepannya, dan untuk mengetahui sejauh mana kontribusi yang ditimbulkan setelah program berjalan.

\section{METODE PENELITIAN}

Penelitian Pemberdayaan Ekonomi Masyarakat Pesisir (PEMP) ini akan dilaksanakan di Kecamatan Gerung Kabupaten Lombok Barat, karena memiliki corak kultur yang khas, dengan kondisi masyarakat yang majemuk dan beragam, serta dinamika kehidupan yang selalu berusaha untuk dapat berkembang. Metode yang digunakan pada penelitian ini adalah menggunakan metode deskriptif dengan pendekatan kualitatif, hasil penelitian akan memberikan gambaran atau mendeskripsikan secara sistematis, faktual dan akurat terhadap obyek yang akan diteliti. Nawawi (2003:64) menjelaskan bahwa metode deskriptif adalah sebagai prosedur pemecahan masalah yang diselidiki dengan menggambarkan dan melukiskan keadaan subjek atau objek penelitian pada waktu atau saat sekarang dan berdasarkan fakta-fakta yang tampak sebagaimana adanya.

Populasi adalah jumlah keseluruhan dari subyek yang akan diteliti dalam suatu penelitian, yang menjadi populasi pada penelitian ini adalah pelaku ekonomi pesisir dan petugas yang berkecimpung dalam penanganan langsung. Pemberdayaan Ekonomi

Masyarakat Pesisir (PEMP) di Dusun Taman Desa Taman Ayu Kecamatan Gerung Kabupaten Lombok Barat Tahun 2015 yang berjumlah 120 orang. Sugiyono (2010:68) menjelaskan bahwa sampel adalah bagian dari jumlah dan karakteristik yang dimiliki oleh populasi. Dalam penelitian ini, Desa merupakan wilayah sampel yang meliputi populasi. Dengan demikian besaran sampel yang akan diambil dalam populasi penelitian ini selanjutnya diatur dan ditentukan dalam teknik sampling penelitian. Sugiyono (2006:59) menjelaskan bahwa penentuan jumlah sampel dari populasi yang di kembangkan oleh Isak dan Michael (penelitian ini dilakukan dengan tingkat kesalahan $10 \%$ (sepuluh persen), dari jumlah pelaku ekonomi pesisir di Dusun Taman Desa Taman Ayu Kecamatan Gerung Kabupaten Lombok Barat Tahun 2015 sebesar 110 populasi, jadi jumlah yang diambil menurut ukuran sampel sebesar 10 orang sebagai anggota sampel yang berkaitan langsung dengan Pemberdayaan Ekonomi Masyarakat Pesisir (PEMP) meliputi kelompok sasaran dan petugas yang berkecimpung dalam penanganan langsung 
Pemberdayaan Ekonomi Masyarakat Pesisir (PEMP) di Dusun Taman Desa Taman Ayu Kecamatan Gerung Kabupaten Lombok Barat Tahun 2015.

Metode pengumpulan data yang digunakan dalam penelitian ini adalah metode observasi, wawancara, dan metode dokumentasi. Data yang digunakan dalam penelitian ini adalah data kualitatif. Data kualitatif yang dimaksudkan adalah data yang berhubungan dengan Pemberdayaan Ekonomi Masyarakat Pesisir (PEMP) di Dusun Taman Desa Taman Ayu Kecamatan Gerung Kabupaten Lombok Barat Tahun 2015.

Penelitian ini merupakan penelitian kualitatif sehingga dalam menganalisa data menggunakan pendekatan deskriftif kualitatif. Selanjutnya sesuai dengan apa yang dikatakan Moleong bahwa langkah teknik analisa data digunakan sehubungan dengan penelitian ini adalah sebagai berikut:

a) Reduksi data dilakukan dengan cara membuat abstraksi. Abstraksi merupakan usaha membuat rangkuman, proses dan pernyataan-pernyataan yang perlu dijaga sehingga tetap didalamnya.

b) Display data yaitu menyajikan data sesuai dengan kategori dalam bentuk matrik atau grafik sehingga data yang terkumpul dapat memberi gambaran secara menyeluruh tentang apa yang menjadi fokus penelitian.

c) Penafsiran dan kesimpulan data yaitu peneliti melakukan penekanan pada butir-butir yang merupakan kunci dan mengkaji informasi kunci yang dimaksudkan secara cermat sebagai suatu kesimpulan.

Gambar 1. Komponen Analisis Data

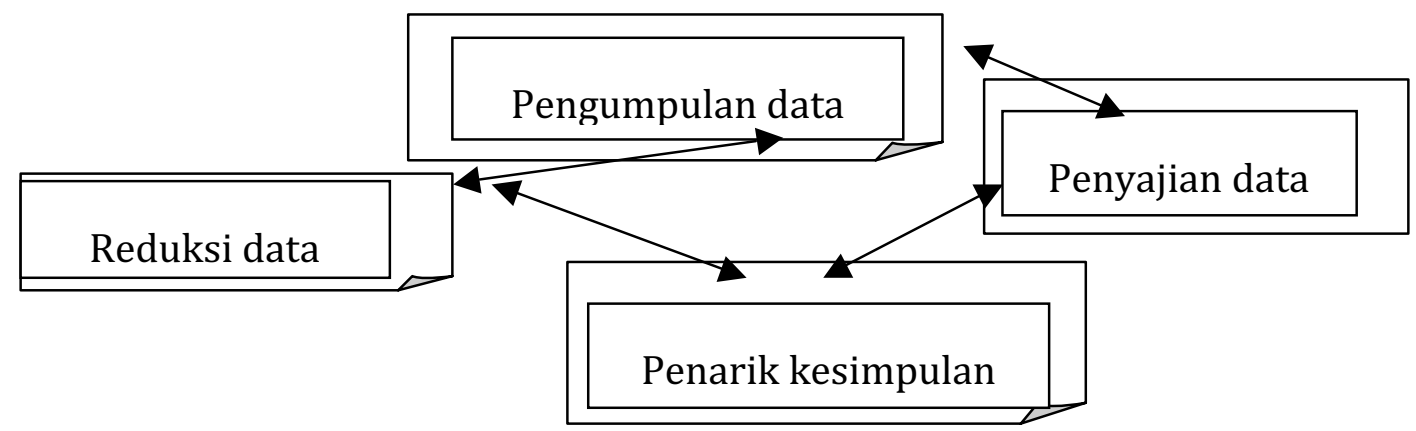

(Miles dan Huberman, 2008:338)

\section{ANALISIS DAN PEMBAHASAN}

Penelitian Pemberdayaan Ekonomi Masyarakat Pesisir (PEMP) ini akan dilakukan di Kecamatan Gerung Kabupaten Lombok Barat, karena memiliki corak kultur yang khas, dengan kondisi masyarakat yang majemuk dan beragam, sertaa dinamika kehidupan yang selalu berusaha untuk dapat berkembang. Lokasi penelitian tersebut mudah dijangkau, sesuai dengan kemampuan tenaga yang dimiliki, dan sesuai dengan waktu yang direncanakan.

Jumlah pelaku ekonomi pesisir di Dusun Taman Desa Taman Ayu yang diambil menurut ukuran sampel sebesar 12 orang sebagai anggota sampel yang berkaitan langsung dengan Pemberdayaan Ekonomi Masyarakat Pesisir (PEMP) meliputi kelompok sasaran dan petugas yang berkecimpung dalam penanganan langsung Pemberdayaan Ekonomi Masyarakat Pesisir (PEMP) di Dusun Taman Desa Taman Ayu Kecamatan Gerung Kabupaten Lombok Barat Tahun 2013 yaitu: 1) Pegawai Kantor Bappekab: a. Sutrisno Hadi selaku Kepala Bappekab Kabupaten Lombok Barat, b. Fauzi selaku Kepala Bidang Sosial Budaya Bappekab Kabupaten Lombok Barat. 2. Aparat Kecamatan, a) Bq. Yeni Satriani Ekawati, S.Sos, selaku Camat Kecamatan Gerung, b) Haryanto selaku Kasi PMD Kecamatan Gerung. 3. Aparat Desa; a) Lalu Junaidi, selaku Kades Taman Ayu Kecamatan Gerung Kabupaten Lombok Barat tahun 2012, b) Fathurrahman selaku Kasi PMD Kecamatan Gerung Kabupaten Lombok Barat. 4) Pengurus BKM; a) Abdurrahman selaku Ketua BKM Swamitra Kecamatan Gerung Kabupaten Lombok Barat, b) Cici pengurus BKM Swamitra. Kecamatan Gerung Kabupaten Lombok Barat. 5) Sejumlah Kelompok Swadaya Masyarakat di Gerung Kabupaten Lombok Barat, 6) Dwi Andri selaku fasilitator Kecamatan Gerung. 
Penelitian ini juga menggunakan data pendukung yang bersumber dari dokumen yaitu catatan yang berkaitan dengan masalah penelitian, diantaranya adalah dokumen Kabupaten Lombok Barat dalam Angka, Kecamatan Gerung dalam Angka, Profil Kecamatan Gerung Kabupaten Lombok Barat, Pedoman Teknis Pemberdayaan Ekonomi Masyarakat Pesisir (PEMP), Laporan Pengurus BKM Swamitra.

Desa Taman Ayu merupakan wilayah pesisir memiliki arti strategis karena merupakan wilayah peralihan antara ekosistem darat dan laut, serta memiliki potensi sumberdaya alam dan jasa-jasa lingkungan yang sangat kaya. Namun, karakteristik laut tersebut belum sepenuhnya dipahami dan diintegrasikan secara terpadu. Kebijakan pemerintah yang sektoral dan bias daratan, akhirnya menjadikan laut sebagai kolam sampah raksasa. Dari sisi sosial-ekonomi, pemanfaatan kekayaan laut masih terbatas pada kelompok pengusaha besar dan pengusaha asing. Nelayan sebagai jumlah terbesar merupakan kelompok profesi paling miskin di Indonesia.

Kekayaan sumberdaya laut tersebut menimbulkan daya tarik bagi berbagai pihak untuk memanfaatkan sumberdayanya dan berbagai instansi untuk meregulasi pemanfaatannya. Kekayaan sumberdaya pesisir, meliputi pulau-pulau besar dan kecil sekitar 17.500 pulau, yang dikelilingi ekosistem pesisir tropis, seperti hutan mangrove, terumbu karang, padang lamun, berikut sumberdaya hayati dan non-hayati yang terkandung di dalamnya.

Akan tetapi, kekayaan sumberdaya pesisir tersebut mulai mengalami kerusakan. Sejak awal tahun 1990-an, fenomena degradasi biogeofisik sumberdaya pesisir semakin berkembang dan meluas. Laju kerusakan sumberdaya pesisir telah mencapai tingkat yang mengkhawatirkan, terutama pada ekosistem mangrove terumbu karang dan estuari (muara sungai).

Penduduk merupakan salah satu aspek dalam pembangunan, yaitu sebagai modal pembangunan sekaligus sebagai penghambat pembangunan, karena majunya suatu daerah sangat tergantung pada kualitas dan kuantitas sumber daya manusianya, oleh karena itu sebagai aspek yang sangat penting dan besar pengaruhnya terhadap kemajuan suatu daerah, maka perlu diupayakan pembangunan baik yang berkaitan dengan materi maupu spritual. Jumlah penduduk di Desa Taman Ayu Kecamatan Gerung Kabupaten Lombok Barat adalah 3674 jiwa yang terdiri atas 1886 jiwa laki-laki dan 1788 jiwa penduduk perempuan. Untuk lebih jelasnya dapat dilihat di Tabel 1 berikut ini.

Tabel 1

Jumlah Penduduk Berdasarkan Umur dan Jenis Kelamin Masyarakat Dusun Taman Desa Taman Ayu Kecamatan Gerung Kabupaten Lombok Barat Tahun 2016

\begin{tabular}{ccc}
\hline USIA (tahun ) & LAKI-LAKI & PEREMPUAN \\
\hline $0-1$ & 28 Orang & 20 Orang \\
$2-4$ & 123 Orang & 107 Orang \\
$5-6$ & 70 Orang & 89 Orang \\
$7-12$ & 253 Orang & 228 Orang \\
$13-15$ & 109 Orang & 110 Orang \\
$16-18$ & 125 Orang & 85 Orang \\
$19-25$ & 251 Orang & 277 Orang \\
$26-35$ & 322 Orang & 397 Orang \\
$36-45$ & 276 Orang & 257 Orang \\
$46-50$ & 100 Orang & 67 Orang \\
$51-60$ & 94 Orang & 90 Orang \\
$61-75$ & 64 Orang & 38 Orang \\
Total & 1886 Orang & 1788 Orang \\
\hline
\end{tabular}

Sumber data : Kantor Desa (dikutip tanggal, 16 Maret 2016)

Keberhasilan pembangunan sangat tergantung dari tingkat pendidikan penduduk, oleh karena itu peningkatan tingakat pendidikan merupakan salah satu indikator dalam penetunan pencapaian angka indeks pembangunan manusia (IPM) yang tinggi. Masalah pendidikan merupakan masalah yang cukup dijadikan barometer dalam melihat tingakat kemajuan suatu daerah, sementara maju mundurnya pedidikan tidak terlepas dari ketersedian berbagai lembaga pendidikan beserta sarana dan prasarana seperti gedung kolah pada berbagai tingkat dengan berbagai fasilitas pendukung hingg tenaga pengajar. 
Tingkat pendidikan berhubungan dengan pengetahuan yang di miliki oleh masyarakat, yang selanjutnya sangat diperlukan dalam hal pelaksanaan pekerjaan dan sikapnya atas pendidikan anaknya untuk menghadapi masa depan yang memiliki masalah lebih kompleks. Dengan pendidikan yang tergolong tinggi masyarakat akan dapat dengan mudah menyerap informasi dalam pelaksanaan pekerjaan dan mepunyai inovasi dalam pengembangan ekonomi keluarganya. Inovasi yang dimaksud adalah dapat dilakukannya perbaikan-perbaikan dala melakukan perkerjaan dan mengatur pendapatannya yang lebih bersifat ekonomi produktif. Informasi mengenai tingkat pendidikan masyarakat Desa Taman Ayu Kecamatan Gerung Kabupaten Lombok Barat dapat di lihat pada Tabel 2 berikut:

Tabel. 2

Tingkat Pendidikan Masyarakat Dusu Taman Desa Taman Ayu Kecamatan Gerung Kabupaten Lombok Barat Tahun 2016

\begin{tabular}{cc}
\hline Tingkat pendidikan & Laki-laki/Perempuan \\
\hline Usia 18-56 pernah SD tetapi tidak tamat & $\mathbf{2}$ \\
Tamat SMP/Sederajat & 540 \\
Tamat SMA/Sederajat & 336 \\
Tamat D-1/Sederajat & 163 \\
Tamat D-2/Sederajat & - \\
Tamat D-3/Sederajat & - \\
Tamat S-1/Sederajat & 15 \\
Tamat S-2/Sederajat & 8 \\
Tamat S-3/Sederajat & - \\
\hline
\end{tabular}

Sumber data : Kantor Desa (dikutip tanggal, 18 Maret 2016)

Dari Tabel 2 pada halaman yang sebelumnya menunjukan bahwa tingkat pendidikan masyaratakat Desa Taman Ayu terbesar adalah sampai SMA/Sederajat, jumlah masyarakat yang sekolah sampai SD tetapi tidak tamat sebanyak 540, masayrakat yang tamat SMP sebanyak 336 dan yang tamat SMA sebanyak 163. Sedangkan masyarakat yang sekolah sampai perguruan tinggi sebanyak 23 baik itu kelulusan D-3 sederajat sampai S-3 sederajat. Jadi tingkat pendidikan masyarakat Dusun Taman Desa Taman Ayu bisa tergolong masing lemah, karena masyarakat yang sekolah sampai perguruan tinggi sebesar 23 orang. Selebihnya masyarakat berpendidikan sampai tingkat SMA.

Berdasarkan hasil observasi yang dilaksanakan oleh peneliti bahwa gambaran mata pencaharian atau tingkat ekonomi penduduk Desa Taman Ayu antara lain, dapat dilihat di Tabel 3 berikut ini yaitu data tentang jenis mata pencaharian.

Tabel 3.

Mata pencaharian penduduk Dusu Taman Desa Taman Ayu

Kecamatan Gerung Kabupaten Lombok Barat Tahun 2016

\begin{tabular}{ccc}
\hline JENIS PEKERJAAN & LAKI-LAKI & PEREMPUAN \\
$\mathbf{1}$ & $\mathbf{2}$ & $\mathbf{3}$ \\
\hline Petani & - & - \\
Buruh tani & - & - \\
Buruh migran perempuan & - & - \\
Buruh migran laki-laki & - & - \\
Pegawai negri sipil & 4 & 2 \\
Pengerajin industri RT & - & 4 \\
Pedagang keliling & 20 & 5 \\
Peternak & - & - \\
Nelayan & 105 & - \\
Dokter swasta & - & - \\
Pembantu rumah tangga & 7 & 13 \\
\hline
\end{tabular}




\begin{tabular}{ccc}
\hline TNI & 1 & - \\
POLRI & 2 & - \\
Pengusaha kecil & 15 & 17 \\
Notaris & 1 & - \\
Jasa pengobatan alternatif & - & - \\
Pengusaha besar & - & - \\
Arsitektur & 1 & - \\
Seniman/artis & - & 70 \\
Kryawan perushaan swasta & 12 & - \\
Montir & 3 & - \\
Perawat swasta & - & - \\
Bidan swasta & Sumber data: Kantor Desa (dikutip tanggal, 30 April 2016)
\end{tabular}

Sebagaimana telah disebutkan sebelumnya bahwa judul dari skripsi ini adalah Implementasi Program Pemberdayaan Ekonomi Masyarakat Pesisir (PEMP) ini akan dilakukan di Dusun Taman Desa Taman Ayu Kecamatan Gerung Kabupaten Lombok Barat Tahun 2013, yang dimana penelitian ini di khususkan kepada nelayan sebagai masyarakat pesisir. maka data yang dibutuhkan dalam penelitian ini adalah data tentang bagaimanakah Implementasi Program Pemberdayaan Ekonomi Masyarakat Pesisir (PEMP) ini akan dilakukan di Dusun taman Desa Taman Ayu Kecamatan Gerung Kabupaten Lombok Barat Tahun 2015.

Data-data yang diperlukan dalam penelitian ini diperoleh melalui mewawancarai informaninforman yang di anggap perlu oleh peneliti. Setelah melakukan penelitian dengan menggunakan metode observasi, wawancara, dan metode dokumentasi, dan menggunakan informan biasa maupun informan kunci dalam laporan hibah pemula ini, peneliti mendapatkan banyak informasi mengenai Implementasi Program Pemberdayaan Ekonomi Masyarakat Pesisir (PEMP) ini akan dilakukan di Desa Taman Ayu Kecamatan Gerung Kabupaten Lombok Barat Tahun 2015.

Setelah peneliti melakukan observasi di lokasi penelian yaitu di Wilayah masyarakat pesisir Desa Taman Ayu, peneliti melakukan pengamatan di sekitar Wilayah masyarakat pesisir Desa Taman Ayu dengan cara mempehatikan Implementasi Program Pemberdayaan oleh pemerintah. Dan dari hasil observasi tersebut peneliti menyimpulkan bahwa Program Pemberdayaan Ekonomi Masyarakat Pesisir (PEMP) sangat bermanfaat bagi masyarakat nelayan yang berada di Dusun Taman Desa Taman Ayu. Saat melakukan wawancara pada beberapa Informan, banyak sekali ditemukan informasi yang berkaitan dengan Implementasi Program Pemberdayaan Ekonomi Masyarakat Pesisir (PEMP) di Dusun Taman Desa Taman Ayu Kecamatan Gerung Kabupaten Lombok Barat Tahun 2015.

Program Pemberdayaan Ekonomi Masyarakat Pesisir (PEMP) di Dusun taman Desa Taman Ayu Kecamatan Gerung Kabupaten Lombok Barat adalah suatu program pemerintah yang dilaksanakan sebagai salah satu upaya dalam mengatasi masalah kemiskinan khususnya di daerah pedesaan masyarakat pesisr. Program ini merupakan program untuk membentuk masyarakat mampu dan mandiri dalam mengurus dirinya sendiri, yang dalam pelaksanaannya meliputi dua macam kegiatan yaitu kegiatan pengembangan usaha/ekonomi dan pembangunan serta pemeliharaan sarana dan prasarana fisik.

Berdasarkan hasil wawancara dengan Pegawai Kantor Bappekab Kabupaten Lombok Barat menyatakan maksud dan Tujuan Program Pemberdayaan Ekonomi Masyarakat Pesisir (PEMP) sesuai dengan Akte Pendirian No. 78/2000/28 Maret 2014 sebagai berikut: a). Membantu mempercepat upaya penanggulangan kemiskinan masyarakat pesisir, b). Membantu melaksanakan dan memasyarakatkan program-program pemerintah secara umum khususnya pelaksanaan PEMP di Kecamatan Gerung. C). Membantu masyarakat untuk membangun dan mengembangkan potensi keswadayaan dalam bidang ekonomi, sosial untuk peningkatan kesejahteraan masyarakat di Desa Taman Ayu Kecamatan Gerung. (Hasil wawancara dengan Bapak Sutrisno Hadi selaku Kepala Bappekab Kabupaten Lombok Barat, dikutip tanggal 13 April 2016).

Bapak Fauzi selaku Kepala Bidang Sosial Budaya Bappekab Kabupaten Lombok Barat menyatakan bahwa Program Pemberdayaan Ekonomi Masyarakat Pesisir (PEMP), untuk melakukan proses pemberdayaan masyarakat. Menjadi lembaga pengelola dana kredit yang berasal dari Pemberdayaan Ekonomi Masyarakat Pesisir yang secara teknis ditangani oleh Unit Pengelola Keuangan (UPK). (Hasil wawancara, dikutip tanggal, 13 April 2016). 
Keberadaan Program Pemberdayaan Ekonomi Masyarakat Pesisir (PEMP) di Desa Taman Ayu Kecamatan Gerung Kabupaten Lombok Barat, Bapak Drs. M. Ali Saleh selaku Camat Kecamatan Gerung menyatakan bahwa adannya program pemberdayaan ini harus didukung dengan keberadaan Badan Keswadayaan masyarakat (BKM). salah satu BKM yang ada di Kecamatan Gerung adalah BKM Swamitra yang beranggotakan warga yang telah dipilih dan diberi kepercayaan oleh warga masyarakat setempat, seperti perwakilan RT/RW, perwakilan organisasi kemasyarakatan.

BKM Swamitra berbentuk Lini staf. Koordinator atau juga biasa disebut dengan Ketua BKM membawahi beberapa staf, diantaranya yaitu: sekretaris; Unit Pengelola Lingkungan (UPL); Unit Pengelola Keuangan (UPK) dan Unit Pengelola Sosial (UPS). Dalam membantu tugas koordinator, UPK juga membawahi beberapa staf yang terdiri dari: petugas kredit; bendahara dan administrasi. Unit-unit yang berada di bawah Ketua BKM, terkecuali sekretaris, saling berkoordinasi antar unit selain koordinasi langsung dengan Ketua BKM, begitu pula unit/petugas yang berada di bawah UPK.

Tugas sekretaris untuk membantu kegiatan administrasi BKM. UPL bertanggungjawab pada perencanaan, perbaikan serta penataan sarana-prasarana dasar lingkungan dan lain-lain. UPK bertanggungjawab pada pengelolaan pinjaman bergulir dan akses kegiatan yang berkaitan dengan pemupukan dana atau akses modal masyarakat. Sedangkan UPS mengelola hal-hal yang berkaitan dengan kerelawanan, mengelola pusat informasi dan pengaduan masyarakat, dan lain-lain sesuai kesepakatan warga setempat. Untuk petugas kredit mempunyai tugas pokok sebagai penagih ke masyarakat. Dana yang telah dibayar atau dikembalikan dicatat oleh bendahara yang dibantu oleh petugas administrasi.

Hasil wawancara dengan Ketua BKM Swamitra Kecamatan Gerung Kabupaten Lombok Barat, bahwa Program Pemberdayaan Ekonomi Masyarakat Pesisir (PEMP) di Desa Taman Ayu Kecamatan Gerung Kabupaten Lombok Barat mengadakan kegiatan permodalan melalui BKM Swamitra adalah sumber dari : Dana dari Program Pemberdayaan Ekonomi Masyarakat Pesisir (PEMP) dan hasil dari upaya-upaya yang dilakukan oleh BKM. Dana yang diterima BKM Swamitra. pada tahun 2011 melalui PEMP yaitu sebesar Rp. 250.000.000,- dengan alokasi dana sebagai berikut: a). Dana Ekonomi Produktif berjumlah Rp. 202. 168.350, b). Dana Fisik berjumlah Rp. 38.172.150, dan c). Jasa Fasilitator dan Biaya Operasional Rp. 9.659.500,- (Bapak Abdurrachman, dikutip tanggal, 16 April 2016).

Adapun syarat-syarat yang harus dipenuhi untuk mendapatkan dana bantuan/dana pinjaman bergulir Program Pemberdayaan Ekonomi Masyarakat Pesisir (PEMP) oleh BKM Swamitra tersebut adalah 1) Warga Desa Taman Ayu Kecamatan Gerung (KTP atau surat keterangan lain), 2) Warga yang dikategorikan miskin (prioritas yang telah memiliki usaha awal), 3) Membentuk suatu kelompok, 4) Mengajukan proposal usaha, 5) Menandatangani surat perjanjian peminjaman; a) Bersifat tanggung, b) Bunga pinjaman 1,5\% tiap bulan, c) Diangsur selama 18 bulan.

Persyaratan tersebut membuat kelompok masyarakat miskin yang benar-benar mengalami kerentanan sosial dan ketidakberdayaan kurang memiliki akses untuk mendapatkan pinjaman PEMP untuk melakukan usaha ekonomi produktif. Persyaratan tersebut menjadikan tujuan PEMP sebagai pemberdayaan masyarakat miskin kurang tercapai, dimana lebih berorientasi pada pencapaian target ekonomis saja.

Dalam pelaksanaan PEMP, perlu diperhatikan beberapa hal bagi masyarakat dalam mengelola bantuan yang akan diterima melalui lembaga lokal setempat, dalam hal ini BKM. Selain sebagai suatu prasyarat dalam penyaluran dana bantuan/hibah, dimaksudkan juga untuk mewujudkan serta tercapainya visi dan misi daripada program PEMP tersebut. Beberapa hal yang perlu diperhatikan masyarakat adalah 1) Masyarakat menentukan siapa kelompok sasaran, 2) Masyarakat menentukan kelembagaan yang merepresentasikan nilai-nilai dan prinsip-prinsip universal sebagai pimpinan kolektif mereka dalam membangun kemandirian dan keberlanjutan upaya penanggulangan kemiskinan, 3) Masyarakat merencanakan sendiri bagaimana menanggulangi kemiskinan melalui PEMP yang disepakati bersama, 4) Masyarakat menggalang, memanfaatkan, mengoptimalkan dan mengelola sumber daya yang dimilikinya serta sumber daya luar yang diperolehnya, baik dari sumber daya PEMP, pemerintah daerah maupun sumber daya lainnya (melalui program kemitraan serta channeling program), untuk berlatih mengimplementasikan rencana mereka dalam menanggulangi kemiskinan, 5) Masyarakat menentukan bagaimana menata dan membangun lingkungan permukiman yang terpadu, sehat, produktif dan lestari, 6) Melembagakan Komunitas Pembelajar, baik di tingkat masyarakat Kecamatan melalui Komunitas Belajar Kecamatan maupun di tingkat kota/kabupaten dengan Komunitas Belajar Pedesaan, 7) Pemerintah daerah menjalin kemitraan sinergis dengan masyarakat dan kelompok peduli, sejak tahap perencanaan, pelaksanaan, monitoring dan evaluasi hingga tahap pemeliharaan. 
Program PEMP dalam pelaksanaannya melalui beberapa tahapan, yaitu tahap persiapan, tahap pelaksanaan dan tahap pengendalian program dan tahap pelestarian kegiatan. Langkah awal yang dilakukan dalam mempersiapkan pelaksanaan PEMP adalah mensosialisasikan tentang adanya program PEMP ke seluruh lapisan masyarakat. Sosialisasi ini merupakan suatu kegiatan yang cukup penting untuk memperoleh informasi yang lengkap tentang program PEMP itu sendiri. Dengan sosialisasi yang dilakukan secara baik dan maksimal akan memberikan pemahaman yang baik pula kepada masyarakat khususnya masyarakat miskin sebagai sasaran program ini yang pada akhirnya mereka dapat mensukseskan kegiatan ini dalam artian mereka dalam melaksanakan program ini tidak terjadi penyimpangan.

Sejak pertama kali mendapat proyek PEMP, seluruh komponen masyarakat di wilayah Kecamatan Gerung (ketua RW, ketua RT, karang taruna dan wakilnya, tokoh masyarakat, tokoh agama dan kelompok profesi) diundang oleh pak Camat untuk membicarakan proyek tersebut. Melalui penjelasan fasilitator Kecamatan, beberapa RT yang dihuni oleh masyarakat yang tidak termasuk dalam kriteria yang ditentukan dalam PEMP, atau dengan kata lain status sosial ekonomi mereka menengah keatas, memahami apa itu proyek PEMP yang baru muncul tersebut dan menyadari bahwa kebijakan pemerintah itu bukan ditujukan untuk mereka.

Setelah ditetapkan RW atau RT yang mayoritas penduduknya miskin, melakukan sosialisasi kepada semua masyarakat disetiap RT/RW dengan model ceramah melalui undangan Ketua RT/RW di balai atau suatu tempat yang dipandang cukup menampung semua warga. Demikianlah cara yang dilakukan oleh fasilitator dalam memperkenalkan PEMP kepada masyarakat di Kecamatan Gerung.

Kelompok Swadaya Masyarakat (KSM) dalam PEMP merupakan instrumen pemberdayaan masyarakat yang akan ditumbuhkan kemandiriannya. Dengan demikian bukan masyarakat miskin secara perseorangan yang akan diberdayakan, melainkan sejumlah orang dalam masyarakat yang tergabung dalam suatu wadah KSM yang dikenai tindakan (treatment) berupa pemberian kredit usaha ekonomi produktif/pinjaman bergulir. KSM penerima bantuan PEMP harus memenuhi beberapa persyaratan sebagai berikut : a) Beranggota minimal 3 orang (dari rumah tangga yang berbeda), b) Anggota berasal dari keluarga berpenghasilan rendah berdasarkan kesepakatan bersama antara Kepala Desa, tokoh masyarakat, pengurus RT/RW dan warga masyarakat lainnya, c) Jumlah anggota yang tidak berasal dari keluarga miskin, dibatasi jumlahnya tidak lebih dari sepertiga jumlah anggota KSM.

Tentang pembentukan KSM, Ketua BKM Swamitra Kecamatan Gerung, Lalu Abdurrachman menyatakan: "keberadaan PEMP di Kecamatan kami dirasakan banyak manfaatnya oleh warga masyarakat. Hal ini terbukti dengan tingginya minat warga yang ingin mendapatkan pinjaman bergulir dengan membentuk KSM-KSM baru, sehingga jumlah KSM yang ada di Kecamatan kami yang semula hanya 25 saat ini bertambah menjadi sekitar 308 KSM". (Hasil wawancara dengan Bapak Fathurrahman selaku Kasi PMD Kecamatan Gerung Kabupaten Lombok Barat, dikutip tanggal, 16 Mei 2016).

Peran Badan Keswadayaan Masyarakat (BKM) adalah sebagai motor penggerak masyarakat dalam menanggulangi kemiskinan diwilayahnya. Organisasi masyarakat warga ini dilegalisasi secara hukum sebagai asosiasi/ perhimpunan warga. Untuk memimpin BKM, dipilih pimpinan kolektif yang terdiri dari pribadi-pribadi yang dipercaya warga berdasarkan kriteria kemanusiaan yang disepakati bersama dan dapat mewakili warga dalam berbagai kepentingan dan seorang dari anggota BKM ini ditunjuk sebagai Koordinator BKM.

Peran yang dijalankan BKM adalah mengorganisasikan warga secara partisipatif untuk merumuskan PJM Gerung, menumbuhkan kegiatan pemberdayaan masyarakat miskin agar mampu meningkatkan kesejahteraan mereka, mengawasi proses pemanfaatan dana masyarakat (BLM) yang sehari-hari dikelola oleh UPK, seperti dijelaskan oleh ketua BKM. "dibentuknya BKM Rukun Sejahtera ini adalah memang sebagai pengelola pelaksanaan PEMP di Kecamatan Gerung yang mengatur perguliran dana pinjaman masyarakat sehingga masyarakat benar-benar dapat memanfaatkan dana pinjaman PEMP sebagai modal untuk pengembangan usaha yang dimilkinya.

Dalam pelaksanaan PEMP, perlu diperhatikan beberapa hal bagi masyarakat dalam mengelola bantuan yang akan diterima melalui lembaga lokal setempat, dalam hal ini BKM. Selain sebagai suatu prasyarat dalam penyaluran dana bantuan/hibah, dimaksudkan juga untuk mewujudkan serta tercapainya visi dan misi daripada program PEMP tersebut. Beberapa hal yang perlu diperhatikan masyarakat adalah:

1. Masyarakat menentukan siapa kelompok sasaran;

2. Masyarakat menentukan kelembagaan yang merepresentasikan nilai-nilai dan prinsipprinsip universal sebagai pimpinan kolektif mereka dalam membangun kemandirian dan keberlanjutan upaya penanggulangan kemiskinan. 
3. Masyarakat merencanakan/menentukan sendiri bagaimana menanggulangi kemiskinan melalui PJM Pronangkis yang disepakati bersama

4. Masyarakat menggalang, memanfaatkan, mengoptimalkan dan mengelola sumber daya yang dimilikinya serta sumber daya luar yang diperolehnya, baik dari sumber daya PEMP, pemerintah daerah maupun sumber daya lainnya (melalui program kemitraan serta channeling program), untuk berlatih mengimplementasikan rencana mereka dalam menanggulangi kemiskinan

5. Masyarakat menentukan bagaimana menata dan membangun lingkungan permukiman yang terpadu, sehat, produktif dan lestari

6. Melembagakan Komunitas Pembelajar, baik di tingkat masyarakat Kecamatan melalui Komunitas Belajar Kecamatan maupun di tingkat kota/kabupaten dengan Komunitas Belajar Perkotaan.

7. Pemerintah daerah mampu memfungsikan KPK-D dalam menyusun SPK-D berbasis aspirasi serta kebutuhan masyarakat.

8. Pemerintah daerah menjalin kemitraan sinergis dengan masyarakat dan kelompok peduli, sejak tahap perencanaan, pelaksanaan, monitoring dan evaluasi hingga tahap pemeliharaan. (Hasil wawancara dengan Ibu Cici pengurus BKM Swamitra Kecamatan Gerung Kabupaten Lombok Barat, dikutip tanggal, 14 Mei 2016).

Salah satu pendekatan yang dinilai efektif dan mampu meningkatkan produksi, pendapatan dan kesejahteraan masyarakat pesisir adalah pendekatan agribisnis dan agroindustri. Kegiatan ini dengan melibatkan secara utuh subsistem input, subsistem produksi, subsistem pengolahan hasil, subsistem pemasaran dan subsitem kelembagaan keuangan maupun kelembagaan penyuluhan. Wilayah pesisir memiliki arti strategis karena merupakan wilayah peralihan antara ekosistem darat dan laut, serta memiliki potensi sumberdaya alam dan jasa-jasa lingkungan yang sangat kaya. Namun, karakteristik laut tersebut belum sepenuhnya dipahami dan diintegrasikan secara terpadu. Kebijakan pemerintah yang sektoral dan bias daratan, akhirnya menjadikan laut sebagai kolam sampah raksasa.

Dari sisi sosial-ekonomi, pemanfaatan kekayaan laut masih terbatas pada kelompok pengusaha besar dan pengusaha asing. Nelayan sebagai jumlah terbesar merupakan kelompok profesi paling miskin di Indonesia (Hasil wawancara dengan Ibu Dwi Andri selaku fasilitator Kecamatan Gerung Kabupaten Lombok Barat, dikutip tanggal, 16 Mei 2016). Kekayaan sumberdaya laut tersebut menimbulkan daya tarik bagi berbagai pihak untuk memanfaatkan sumberdayanya dan berbagai instansi untuk meregulasi pemanfaatannya. Kekayaan sumberdaya pesisir, meliputi pulau-pulau besar dan kecil sekitar 17.500 pulau, yang dikelilingi ekosistem pesisir tropis, seperti hutan mangrove, terumbu karang, padang lamun, berikut sumberdaya hayati dan non-hayati yang terkandung di dalamnya.

Dalam proses implementasi tidak terlepas dari faktor-faktor yang memberikan pengaruh dalam menentukan keberhasilan ataupun kegagalan. Sejalan dengan pendapat Mazmanian dan Sabatier bahwa: Makna implementasi memahami apa yang senyatanya terjadi sesudah suatu program dinyatakan berlaku atau dirumuskan merupakan fokus perhatian implementasi kebijakan, yakni kejadian-kejadian, dan kegiatan-kegiatan yang timbul sesudah disahkan pedoman-pedoman kebijakan negara yang menyangkut baik usaha-usaha untuk mengadministrasikan maupun untuk menimbulkan akibat/dampak nyata pada masyarakat atau kejadian-kejadian. (2007:86)

Dalam setiap perumusan kebijakan yang berkenaan dengan kepentingan publik selalu diawali dengan tahapan perumusan masalah, dan pada tahap rumusan masalah yang bertujuan memberikan solusi tersebut, tidak terlepas dari proses perencanaan. Rencana adalah $20 \%$ keberhasilan, implementasi adalah $80 \%$ sisanya, $20 \%$ sisanya adalah bagaimana kita mengendalikan implementasi. Implementasi kebijakan adalah hal yang paling berat, karena di sini masalah-masalah yang kadang tidak dijumpai dalam konsep, muncul di lapangan. Selain itu, ancaman utama, adalah konsistensi implementasi. Demi tewujudnya keberhasilan pelaksanaan program PEMP, diperlukan beberapa tahapan kegiatan yang harus dilakukan secara benar dan tepat, yaitu mencakup kegiatan persiapan, pelaksanaan dan tahap yang menerus atau berkala. Untuk itu kajian mengenai pelaksanaan program Pemberdayaan Ekonomi Masyarakat Pesisir (PEMP) di Kecamatan Gerung dalam penelitian ini mencakup indikator-indikator yang telah disebut sebelumnya.

Fasilitator Kecamatan memiliki peran penting dalam keberhasilan proyek. Gagal tidaknya proyek tersebut terletak pada kecakapan dan keuletan fasilitator tersebut dalam mendamping KSM dan BKM untuk memberikan bimbingan dan arahan serta menjadi konsultan dalam pelaksanaan proyek. Fasilitator 
Kecamatan mempunyai tanggung jawab dalam mendorong dan memampukan masyarakat agar berdayaguna dan berhasilguna dalam mengatasi segala persoalan yang mendera mereka.

Kecamatan Gerung, sosialisasi program PEMP belum dilaksanakan dengan baik dan maksimal sehingga sebagian masyarakat belum memahami program PEMP secara benar. Tingkat pemahaman yang relatif rendah ini cenderung akan mengakibatkan terjadinya penyimpangan-penyimpangan dalam menggunakan bantuan pinjaman seperti misalnya penggunaan dana pinjaman tidak untuk kegiatan usaha yaitu untuk kegiatan konsumtif dan akibatnya seringkali terjadi kemacetan dalam pembayaran pinjaman.

Dalam hal ini BKM merupakan wadah yang mengelola perguliran dana PEMP bagi usaha masyarakat. Melalui BKM anggota KSM tersebut dapat memperoleh bantuan yang sifatnya bergulir dengan berbagai ketentuan yang telah disepakati bersama antara KSM dengan BKM.

Pada umumnya, dalam anggota KSM tersebut kurang memiliki kemampuan untuk menyusun atau membuat proposal tentang rincian biaya dan kegiatan usaha yang akan ditekuninya.

Dalam upaya untuk memberdayakan komunitas warga Kecamatan Gerung, ditemui adanya tiga hambatan besar yaitu (1) hambatan yang melekat pada individu seperti keterampilan, pengetahuan, (2) hambatan yang terkait dengan ekonomi seperti kurangnya modal, (3) hambatan yang terkait dengan kondisi lingkungan seperti sarana prasarana dasar lingkungan yang kurang mendukung. Guna menghilangkan hambatan tersebut, dalam PEMP disediakan bantuan yang berupa (1) bantuan kredit modal kerja bergulir untuk kegiatan usaha ekonomi produktif, (2) bantuan dana hibah untuk biaya pembangunan atau perbaikan sarana-prasarana dasar lingkungan, (3) bantuan dana hibah untuk biaya pelatihan ketrampilan kerja dalam rangka penciptaan lapangan usaha baru.

Setiap implemantasi dari suatu program kebijakan akan melahirkan dampak bagi kelompok sasaran yang dituju, baik dampak sosial maupun berdampak secara ekonomi atau mungkin dampak politis serta kultural. Telah dibahas pada awal penelitian bahwa penelitian evaluasi, apa pun aspek yang berusaha disoroti, tidaklah pernah berlangsung dalam suasana yang vacum. Ia pada hakekatnya adalah merupakan aktivitas yang berlangsung dalam konteks sosial-politik tertentu. para politisi, administrator dan kelompok sasaran (pemetik manfaat) dalam memperjuangkan sumber-sumber langka.

Mengingat masyarakat tidak merespon semua komponen yang ditawarkan dalam program PEMP dan kurang perhatiannya BKM dalam memeberdayakan masyarakat, maka hal ini dapat menimbulkan dampak positif dan dampak negatif. Dampak positifnya antara lain: 1) Keuangan PEMP semakin hari semakin meningkat jumlahnya, 2) Dapat memberi kesempatan luas bagi masyarakat/KSM lain yang membutuhkan dana lunak, 3) Dapat menciptakan lapangan kerja baru. Sedangkan dampak negatifnya antara lain 1) Dapat menimbulkan kecemburuan sosial, 2) Kurang kreatif, karena mengharapkan pinjaman ke PEMP setiap membutuhkan dana.

Pembahasan terhadap fokus penelitian tentang partisipasi masyarakat dalam pelaksanaan PEMP di Dusun Taman Desa Taman Ayu Kecamatan Gerung berdasarkan temuan penelitian sebagai berikut: 1) Partisipasi masyarakat dalam aspek pembuatan keputusan program diwujudkan dalam penyusunan program-program penanggulangan kemiskinan dan penyusunan dan pengajuan usulan kegiatan BKM. Partisipasi masyarakat pada kegiatan pembuatan keputusan tersebut di atas dapat digolongkan masih rendah dan pasif, 2) Partisipasi masyarakat dalam aspek penerapan keputusan berwujud partisipasi masyarakat sebagai tenaga kerja proyek, swadaya berupa pemberian makanan dan minuman untuk mereka yang sedang mengerjakan proyek. Partisipasi masyarakat dalam kegiatan ini terlihat dari jumlah masyarakat yang ingin terlibat dalam pembangunan sarana-prasarana dasar lingkungan. Partisipasi sebagai peserta pelatihan.

Jika ditinjau dari aspek partisipasi masyarakat sebagaimana telah dipaparkan dalam hasil temuan penelitian, maka partisipasi masyarakat pada aspek pembuatan keputusan (program) tergolong masih rendah dan pasif, sedangkan pada aspek penerapan keputusan tergolong cukup tinggi, pada aspek pemanfaatan hasil dan pelestariaannya partisipasi masyarakat tergolong cukup tinggi, sedangkan pada aspek evaluasi partisipasi masyarakat sudah menampakkan wujudnya.

Proyek Penanggulangan Kemiskinan di Perkotaan (PEMP) merupakan upaya pemerintah dalam menanggulangi kemiskinan dengan memberikan kewenangan yang lebih besar kepada masyarakat untuk secara aktif merencanakan, melaksanakan, memelihara dan mengawasi pelaksanaan program.

Berdasarkan pemikiran di atas maka dapat dikatakan bahwa keberhasilan pelaksanaan Proyek Penanggulangan Kemiskinan di Perkotaan (PEMP) di Kecamatan Gerung karena didukung oleh partisipasi, kesadaran dan rasa tanggung jawab masyarakat. Mengingat bahwa penerapan pola penanggulangan kemiskinan dalam proyek PEMP juga dilaksanakan di beberapa kota dan kabupaten di Indonesia, namun tingkat keberhasilan programnya bervariasi. 
Hal ini pula yang terjadi di lokasi penelitian di Kecamatan Gerung khususnya di Kecamatan Gerung sebagaimana telah diuraikan di atas. Secara garis besar pola itu dapat dijelaskan sebagai berikut: proses penanganan PEMP diawali dengan serangkaian kegiatan orientasi pemahaman substansi PEMP kepada semua pihak pelaksana PEMP mulai dari tingkat pusat hingga Kecamatan yang dimaksudkan agar semua komponen pelaku dan pihak terkait dapat memahami secara utuh dan memiliki persepsi yang sama mengenai visi, misi, tujuan, strategi, prinsip dan nilai serta mekanisme pelaksanaan PEMP.

Disadari bahwasannya dalam implementasi program pembangunan selalu terjadi kesenjangan antara aturan pelaksanaan dan realisasi kegiatan di lapangan. Begitu juga yang terjadi dalam implementasi PEMP di Kabupaten Lombok Tengah tepatnya di Kecamatan Gerung. Hambatan yang terjadi diidentifikasikan oleh peneliti terjadi pada tiga pelaku PEMP yakni Badan Keswadayaan Masyarakat (BKM), Kelompok Swadaya Masyarakat (KSM) dan Masyarakat.

Dari beberapa faktor yang mempengaruhi keberhasilan program PEMP diatas, juga tidak luput dari beberapa kendala yang dialami oleh BKM Rukun Sejahtera dalam pelaksanaan program diantaranya adalah : 1) Dana yang tersedia hanya dalam jumlah terbatas, sehingga tidak mencakup seluruh warga Kecamatan yang menjadi sasaran program sehingga menimbulkan sulitnya program berjalan cepat dan masih kurang dipahaminya sebagian masyarakat akan tujuan program secara jelas karena ada sebagian anggapan masyarakat bahwa dengan tidak dipenuhinya oleh bantuan fisik untuk pembangunan jalan mereka dianggapnya BKM tidak merata penyebarannya, 2) Kurangnya koordinasi antara pengurus BKM/KSM dengan anggotanya sehingga program tidak berjalan optimal, 3) Pemahaman mengenai konsep pelaksanaan program masih kurang mengakibatkan masyarakat menjadi apatis terhadap program, 4) Pembagian kerja yang belum jelas dari masing-masing bidang pengurus BKM sehingga menimbulkan tumpang tindih antara pengurus BKM.

Hambatan yang terjadi dalam implementasi PEMP ini diklasifikasikan oleh peneliti menjadi tiga yakni: kategori, sifat penanganan dan hal/masalah: 1) Tidak tertibnya penatabukuan BKM dalam mengadministrasikan keuangan PEMP. Akibat pertama adalah tidak diketahuinya posisi keuangan PEMP, berapa piutang, pendapatan jasa dll. Selanjutnya berakibat tidak terkontrolnya pengeluaran yang kadangkadang melebihi pendapatan jasanya, 2) Terdapat KSM bermasalah/nakal yang menunggak angsuran pembayaran pinjaman. Hal ini tidak bisa dibiarkan berlarut karena bisa berakibat fatal. Diusahakan agar pinjaman bergulir yang diluncurkan ke KSM dapat ditagih dan dipergunakan kembali untuk memberi kredit kepada KSM lain yang juga membutuhkannya.

\section{KESIMPULAN}

Berdasarkan hasil penelitian dan pembahasan terhadap fokus permasalahan dalam penelitian ini, maka dapat diambil beberapa kesimpulan sebagai berikut: 1) Implementasi PEMP di Dusun Taman Desa Taman Ayu Kecamatan Gerung belum dilaksanakan secara optimal sesuai dengan kebijakan yang telah dirumuskan. Pelaksanaan kebijakan PEMP dalam pemberdayaan masyarakat miskin di Kecamatan Gerung terdiri dari empat tahap, antara lain yaitu tahap persiapan; tahap pelaksanaan; tahap pengendalian; dan tahap pelestarian. Pemanfaatan dana bantuan telah sesuai dengan tiga komponen kegiatan yang menjadi sasaran tujuan program PEMP, yaitu ekonomi produktif; pelatihan dan pembangunan sarana dan prasarana dasar lingkungan. Namun masih ada sejumlah anggota KSM yang memanfaatkan bantuan tersebut untuk kegiatan konsumtif. Pembentukan BKM dan KSM dilaksanakan secara demokratis, transparansi, dan jujur, karena kedua lembaga lokal inilah yang berinteraksi dalam pelaksanaan PEMP, 2) Dampak yang ditimbulkan dalam pelaksanaan PEMP dibagi menjadi dua, yaitu: Dampak positifnya antara lain a) Keuangan PEMP semakin hari semakin meningkat jumlahnya, b) Dapat memberi kesempatan luas bagi masyarakat/KSM lain yang membutuhkan dana lunak, c) Dapat menciptakan lapangan kerja baru. Dampak negatifnya antara lain: a) Dapat menimbulkan kecemburuan social, b) Kurang kreatif, karena mengharapkan pinjaman ke PEMP setiap membutuhkan dana.

Dalam pelaksanaan PEMP di Desa Taman Ayu Kecamatan Gerung terdapat faktor pendukung dan faktor penghambat. Faktor pendukung keberhasilan pelaksanaan program PEMP di Desa Taman Ayu Kecamatan Gerung, yaitu: a) Partisipasi masyarakat terhadap program, b) Kelembagaan masyarakat yang efektif, c) Kemudahan dalam memperoleh bantuan, d) Kesadaran masyarakat. Faktor penghambat pelaksanaan PEMP, yaitu: a) Dana yang tersedia hanya dalam jumlah terbatas, sehingga tidak mencakup seluruh warga Kecamatan yang menjadi sasaran program, b) Kurangnya koordinasi antara pengurus $\mathrm{BKM} / \mathrm{KSM}$ dengan anggotanya sehingga program tidak berjalan optimal, c) Pemahaman mengenai konsep 
pelaksanaan program oleh masyarakat masih kurang, d) Pembagian kerja yang belum jelas dari masingmasing bidang pengurus BKM sehingga menimbulkan tumpang tindih antara pengurus BKM.

Hasil penelitian menunjukan beberapa hal yang berkaitan dengan pelaksanaan program PEMP dengan pemberdayaan kepada masyarakat, oleh karena itu penelitian ini menyarankan untuk diperhatikan yaitu antara lain: a) Menghadapi kondisi keuangan atau dana yang terbatas, kepada pengurus BKM lebih aktif dalam proses penagihan ke KSM-KSM yang terlambat atau menunggak untuk menghindari terjadinya kredit macet yang pada akhirnya akan berpengaruh kepada pelestarian kegiatan PEMP tersebut, b) Dari hasil penelitian ini diperoleh temuan jika koordinasi antara pengurus BKM/KSM dengan anggotanya dinilai kurang, sehingga program tidak berjalan optimal. Maka peneliti dapat menyarankan untuk diadakan pertemuan rutin minimal satu kali dalam sebulan antara pengurus BKM yang didampingi oleh fasilitator Kecamatan serta dihadiri oleh aparat pemerintah daerah, dari tingkat Kabupaten hingga Kecamatan, serta KSM dan anggotanya untuk menampung aspirasi yang

\section{DAFTAR PUSTAKA}

Arifin. (2002). Metode Konsep Penelitian Kualitatif. Retrieved from www//htfn metode $=$,daa $=$ konsep $=$ venelitian $\% 0 \mathrm{~A}=$ kualitadf $=$ danpen=banpunan.et $\% 0 \mathrm{~A}$

Arikunto, S. (2005). Prosedur Peneltian Suatu Pendekatan Praktek. Jakarta: Rineka Cipta.

Arsyad Lincolin. (2010). Ekonomi Pembangunan, edisi 5, cetakan Pertama. Yogyakarta: UPP STMIK YKPN.

Bintoro. (1991). Lingkungan Sosial dan Persaingan. Retrieved from www//http.socialpersaingan $7 \% 09$ lingkungan-masyarakatworocorrt.et

Jones. (1991). Aspek_Sosial_Ekonomi_Masyarakat_Pesisir. Bandung: Alfabet.

Kementrian Prekonomian Dan Kelautan. (2006). Pedoman Umum Pelaksanaan Program Pemberdayaan Ekonomi Masyarakat Pesisir (Pendum PEMP).

Komarudin. (2000). Metode dan Penelitian. Retrieved from ww//httn.metode--dan=fwnsepwenelifian.ex

Pabundu. (2005). Penelitian Kualitatif edisi cetakan pertama (Vol. 5). Jakarta: Rineka Cipta.

Soekanto, S. (1982). Sosiologi Suatu Pengantar. Jakarta: Raja Wali Press. https://doi.org/10.1163/_q3_SIM_00374

Sugiono. (2003). Metode penetian kualitatif, kuantitatif, $R \& D$. Bandung: Alfabeta.

Suharto Toto. (2005). Demokrasi Pendidikan Konsep Dasar Pendidikan Berbasis masyarakat. Retrieved from http://www.toto.go.id/Jurnall28lpdf

Sukriono Didik. (2010). Pembaruan hukum pemerintah Desa potitik hukum pemerintah Desa di Indonesia. Malang: setara Press.

Sutrisno. (1984). Metode Penelitian. https://doi.org/10.1007/s13398-014-0173-7.2

Wiranto Tata. (2007). Profil kemiskinan di perdesaan. Direktur Kerjasama Pembangunan Sektoral Dan Daerah, Bappenas, Info URDI, 14, 1-9. 